\title{
Otomatisasi Sensor Load Cell untuk Mengatasi Overload Kendaraan
}

\author{
Rahmadi Kurnia $^{1 *}$, Rifki Firdaus ${ }^{1}$, Lucyana Lufti ${ }^{1}$, Muhammad Habib Anshor ${ }^{2}$ \\ ${ }^{1}$ Jurusan Teknik Elektro, Fakultas Teknik, Universitas Andalas \\ ${ }^{2}$ Jurusan Teknik Mesin, Fakultas Teknik, Universitas Andalas \\ ${ }^{*}$ Corresponding author, e-mail: kurnia@eng.unand.ac.id
}

\begin{abstract}
Abstrak - Kelebihan muatan merupakan suatu hal yang sering diabaikan oleh para pengemudi. Padahal, kelebihan muatan memberikan dampak di berbagai sisi. Peningkatan emisi gas buang, kerusakan badan jalan, bahkan kecelakaan lalu lintas dapat diakibatkan oleh kelebihan muatan kendaraan. Jembatan timbang merupakan seperangkat alat untuk menimbang kendaraan yang dipasang secara tetap merupakan solusi yang ditawarkan pemerintah untuk mengatasi masalah tersebut. Namun sayangnya masih sering ditemukan pengemudi yang mengangkut beban melebihi batas angkut yang ditetapkan oleh pemerintah. Tujuan perancangan ini adalah menghasilkan prototipe kendaraan bak terbuka yang mampu mencegah mesin kendaraan tersebut beroperasi dengan kondisi beban berlebih dengan mengetahui hasil pembacaan sensor load cell. Perancangan sistem dan prototipe ini merupakan perancangan yang menyerupai sistem lift. Alarm peringatan, pintu tidak dapat ditutup serta lift tidak dapat dioperasikan merupakan indikator yang menandai bahwa lift dalam kondisi kelebihan muatan. Dengan mengadopsi sistem lift ini, maka dirancanglah suatu prototip machine-stopping system suatu sistem built-in yang terdiri dari komponen berupa, sensor load cell, buzzer, relay, LED dan motor servo yang akan menghalangi kendaraan beroperasi dalam keadaan kelebihan muatan. Sensor beban diletakan pada chassis kendaraan yang mengalami pelendutan maksimal berdasarkan perhitungan total perubahan gaya yang diberikan pada kendaraan. Perubahan beban yang diberikan pada rangka menimbulkan gaya akibat deformasi material akibat adanya tegangan mekanis yang bekerja. Perubahan tegangan tersebut akan diubah oleh sensor beban menjadi sinyal listrik. Karena perubahan tegangan yang dihasilkan oleh sensor beban dalam skala $\mathrm{mV} / \mathrm{V}$, digunakan modul sensor berat yaitu $\mathrm{HX} 711$ sebagai amplifier agar dapat diolah oleh mikrokontroler. Hasil penguatan tersebut memerintahkan arduino untuk komponen bekerja sehingga mengahalangi kendaraan beroperasi dalam kondisi beban belebih.
\end{abstract}

Kata Kunci : kelebihan muatan, load cell, machine-stopping system

\begin{abstract}
Overloading is something that is often ignored by drivers. In fact, overload has an impact on various sides. Increased exhaust emissions, road damaged, even traffic accidents can be caused by overloading vehicles. The weighbridge is a set of tools for weighing vehicles that permanently installed is the solution offered by the government to fix the problem. Unfortunately, drivers are often found carrying loads exceeding the transport limits. The purpose of this design is to produce a prototype of truck that is able to prevent the vehicle's engine from operating under conditions of overload by knowing the results of load cell sensor readings. The system design and prototype as a design that resembles an elevator system. Alarm, door cannot be closed and lift cannot be operated are indicators indicate that the elevator is in an overload condition. By adopting this elevator system, a prototype machine-stopping system was designed, a built-in system consisting of components in the form of buzzers, relay, LED and servo motors that would block a vehicle from operating in a overload condition. The load cell will be placed on chassis which has maximum deflection based on the total change of force that applied to the vehicle. The changes in load on the chassis causes the force due to deformation of the material. The change in voltage will be converted by load cell sensor into an electrical signal. Because the change in voltage generated by the load cell on an $\mathrm{mV} / \mathrm{V}$ scale, a load cell sensor module, HX711 module, is used as an amplifier to be processed by a microcontroller. The result of HX711 module informs Arduino to ordered components block a vehicle operating in overload condition.
\end{abstract}

Keywords : overloading, load cell, machine-stopping system

Received date 2019-07-27, Revised date 2019-08-07, Accepted date 2019-08-08

https://doi.org/10.25077/jnte.v8n2.666.2019

This work is licensed under a Creative Commons Attribution-ShareAlike 4.0 International License. 


\section{Pendahuluan}

Perkembangan dan peningkatan pengguna kendaraan terkhusus kepada peningkatan penggunaan kendaraan barang atau orang seperti bus dan truk memiliki dampak merugikan yang sering kali diabaikan. Dampak yang sering kali diabaikan akibat penggunaan kendaraan adalah kelebihan muatan atau overload pada kendaraan. Kelebihan muatan kendaraan merupakan suatu keadaan muatan yang diangkut oleh kendaraan melebihi batas maksimum beban yang ditetapkan [1]. Kelebihan muatan memberikan multiplier effects yang berpengaruh langsung terhadap berbagai bidang kehidupan.

Kelebihan muatan pada kendaraan akan mengakibatkan kemacetan karena kendaraan yang mengalami kelebihan muatan tidak mampu berjalan dengan kecepatan rata-rata sehingga akan mengganggu aktivitas dan kenyamanan di jalan raya. Kelebihan muatan akan mengakibatkan kerusakan struktur jalan, yaitu kerusakan pada pengerasan jalan sehingga akan mengurangi umur rencana pengerasan jalan [2].

Kelebihan muatan bahkan menyebabkan peningkatan emisi gas buang kendaraan, yaitu karbon dioksida $\left(\mathrm{CO}_{2}\right)$. Peningkatan karbon dioksida pada kendaraan yang mengalami kelebihan muatan terjadi akibat peningkatan konsumsi bahan bakar minyak (BBM) dari kerja mesin yang berat [3].

Upaya pencegahan terhadap kelebihan muatan telah dilakukan oleh berbagai pihak. Sebagai upaya untuk mengatasi kelebihan muatan pemerintah telah menetapkan peraturan pembatasan dari maksimal beban angkut kendaraan yang tercantum dalam UU No. 22 Tahun 2009 yang dilakukan dengan menggunakan alat penimbangan. Penanggulangan untuk mengatasi kelebihan muatan dengan menggunakan alat penimbangan atau jembatan timbang tersebut belum berjalan dengan efektif karena masih banyak pengendara yang tidak mematuhi aturan muatan kendaraan. Alat penimbangan yang diterapkan pemerintah ini bersifat tetap, hanya bisa menimbang muatan kendaraan pada lokasi-lokasi tertentu, sehingga pada lokasi lain kendaraan dengan muatan berlebih masih tetap beroperasi di jalan.

Perkembangan teknologi juga berupaya mengatasi permasalahan muatan berlebih. Kapasitas angkutan dapat dideteksi dengan menggunakan Automated Ambient Traffic (AAT) pada jembatan yang di-monitoring menggunakan
Structural Health Monitoring (SHM) [4]. Teknologi dan penelitian lain yang berupaya mengatasi kelebihan muatan adalah prototipe mesin pengantar barang otomatis menggunakan load cell dengan berbasis robot line follower. Prototipe mesin pengantar barang tersebut mencegah mesin beroperasi dalam keadaan beban berlebih. Prototipe ini hanya dikembangkan pada mesin pengantar barang, bukan pada kendaraan [5].

Di sisi lain teknologi untuk membatasi muatan telah diterapkan pada alat transportasi gedung yang dikenal dengan elevator atau lift. Lift adalah alat pengangkat yang digunakan khusus untuk mengangkat atau memindahkan barang atau orang secara vertikal dengan cara naik turun (hoist) yang ditarik dengan menggunakan pully yang digerakkan oleh motor listrik. Teknologi pembatas beban pada lift bekerja sebelum lift beroperasi sehingga mencegah terjadinya kecelakaan atau kerusakan pada lift akibat kelebihan muatan. Sangat jarang terjadi kecelakaan akibat overload pada lift. Perkembangan penelitian terkait lift yaitu rancang bangun model lift 3 lantai dengan menggunakan PLC sebagai pengendali [6]. Perancangan tersebut berfokus pada perhitungan prioritas input. Sistem lift ini membatasi pengguna lift dan tujuan pengguna agar tidak terjadi pemborosan energi. Teknologi yang berkembang pada saat belum terfokus kepada pembatasan muatan pada kendaraan saat kendaraan belum dioperasikan. Bahkan teknologi yang digunakan sekarang ini hanya berkembang pada pendeteksian kelebihan muatan kendaraan pada satu titik saja dan pada saat kendaraan sedang beroperasi. Padahal sangat aman dan efektif jika solusi yang diberikan sebelum kendaraan beroperasi.

Alat pembatas beban yang bekerja pada lift terdiri dari sensor pendeteksi beban, peringatan dan penghalang pintu. Berdasarkan prinsip kerja sistem pembatas beban pada lift yang bekerja secara otomatis mendeteksi beban berlebih inilah yang diterapkan dan diadopsi pada kendaraan. Perancangan sistem ini dibuat untuk mengatasi beban berlebih pada kendaraan dengan menggunakan sensor beban load cell yang diletakkan pada rangka (chassis) kendaraan. Kemudian keluaran atau hasil bacaan sensor jika mendeteksi beban berlebih akan secara otomatis mengaktifkan alarm peringatan, menghentikan kerja mesin serta sistem akan menghalangi pintu tertutup sehingga kendaraan dengan kondisi muatan berlebih tidak dapat dioperasikan. Namun, 
jika beban telah dikurangkan dan kendaraan tidak dalam keadaan overload alarm akan mati, mesin kendaraan akan bekerja kembali secara otomatis pula. Perancangan dari machine-stopping system ini berfungsi sebagai solusi untuk mengatasi kelebihan muatan pada kendaraan, sehingga dapat mengurangi resiko akibat kelebihan muatan pada kendaraan.

\section{Metoda}

Secara keseluruhan prototipe Machine-Stopping System (MASS) memiliki dua bagian utama yaitu masukan (sensor load cell), processor (mikrokontroler) dan keluaran (relay, buzzer, LED indikator, dan motor servo). Rancangan dari sistem MASS dapat dilihat pada Gambar 1.

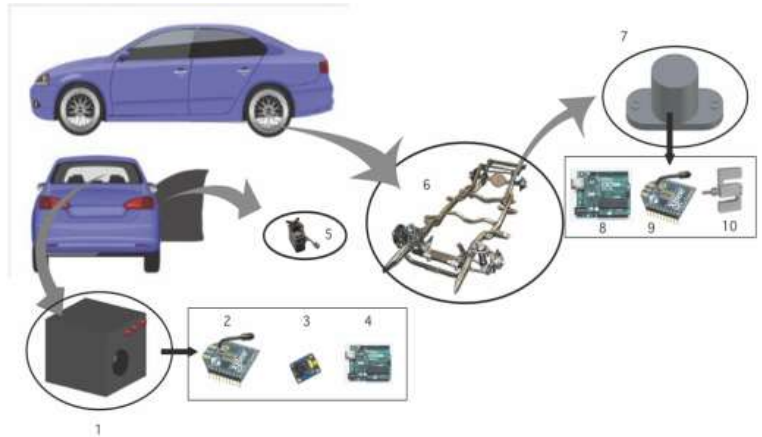

Gambar 1. Desain Sistem MASS

Perancangan terdiri dari dua bagian yaitu bagian masukan dan keluaran. Perangkat keluaran akan membunyikan alarm, mematikan mesin serta mengaktifkan penghalang pintu. Modul xbee berfungsi sebagai serial komunikasi pengirim dan penerima sinyal. Buzzer akan menghasilkan bunyi ketika mendeteksi beban berlebih, channel relay mematikan mesin dan motor servo menghalangi pintu tertutup. Semua indikator tersebut dikendalikan oleh mikrokontroler Arduino. Hasil keluaran tersebut akan aktif jika sensor load cell yang diletakkan pada posisi yang mengalami pelendutan maksimal mendeteksi kelebihan beban.

\subsection{Perancangan Hardware}

Sistem ini bekerja ketika sensor beban load cell yang merupakan sebuah sensor untuk mendeteksi tekanan atau massa sebuah beban mendeteksi perubahan resistansi pada rangka kendaraan. Load cell merupakan transduser elektronik yang dapat mengubah besaran fisik menjadi sinyal elektrik [5]. Prinsip kerja singkat dari load cell adalah ketika terjadi stress atau shears yang diwujudkan dalam perubahan panjang (regangan) permukaan menjadi resistansi. Load cell akan mengubah output hasil pembacaan menjadi sinyal listrik agar mempermudah pengolahan data [7]. Tipe load cell yang digunakan dalam perancangan ini seperti pada Gambar 2 adalah tipe S.

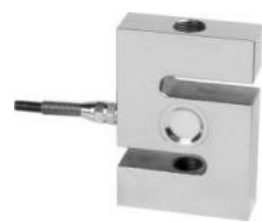

Gambar 2. Sensor load cell tipe S

Sinyal listrik yang dihasilkan sensor load cell dalam ukuran mv/V. Sensor load cell ini dikalibrasi dengan membagi secara proporsional beban maksimum pada sensor tersebut. Pada kegiatan ini beban maksimal pada sensor adalah $250 \mathrm{~kg}$. Sedangkan beban maksimum yang digunakan pada penelitian ini adalah $160 \mathrm{~kg}$. Proses konversi beban maksimum ini akan dilakukan pad a keluaran dari sensor load cell ini.

Selanjutnya, keluaran dari sensor load cell ini akan diperkuat oleh IC pada modul HX711 seperti pada Gambar 3. Hasil dari konversi tersebut dikonversikan ke dalam besaran tegangan melalui rangkaian pada modul. Prinsip kerja dari modul HX711[8] adalah ketika bagian yang lebih elastis pada sensor beban mendapatkan tekanan, maka pada sisi lain akan mengalami perubahan regangan yang sesuai. Hasil pembacaan tersebut berupa data analog diolah dan dilakukan pengkondisian sinyal melalui pin analog mikrokontroler.

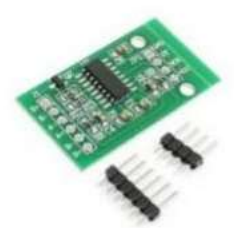

Gambar 3. Modul HX711

Arduino Uno Rev 3 seperti pada Gambar 4 merupakan mikrokontroler yang digunakan untuk mengolah hasil pembacaan sensor beban. Arduino merupakan komputer kecil (electronic prototyping platform) berbasis open source yang dapat diprogram untuk memproses masukan dan keluaran dari berbagai perangkat atau komponen[9]. Arduino akan menerima sinyal tegangan analog dan mengolahnya menjadi sinyal digital dan mengirimkan sinyal kebagian keluaran sistem. 


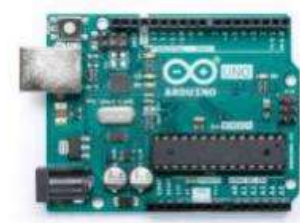

Gambar 4. Arduino Uno Rev 3

Setelah keluaran digital yang telah diolah mikrokontroler didapatkan, Xbee pada bagian masukan berfungsi sebagai radio modules yang akan mengirimkan informasi hasil pembacaan beban tersebut ke bagian keluaran. Modul xbee dirancang sesuai dengan standar IEEE 802.15.4 yang mampu berfungsi sebagai wireless sensor networks dengan daya yang rendah. Modul xbee pada Gambar 5 membutuhkan daya yang rendah yaitu $5 \mathrm{~V}$ mampu diandalkan untuk melakukan pengiriman data hasil pada masukan dan mengirimkan informasi tersebut ke bagian keluaran.

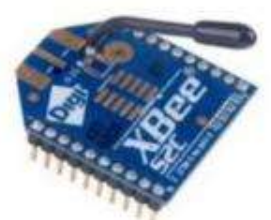

Gambar 5. Model Xbee S2C

Bagian keluaran akan juga terdapat radio modules xbee yang berfungsi sebagai penerima sinyal informasi yang diberikan oleh bagian masukan. Konfigurasi modul xbee agar dapat mengirimkan (transmitter) dan menerima (receiver) data dapat dilihat pada Tabel 1.

Tabel 1. Konfigurasi Radio Wireless Xbee

\begin{tabular}{|c|c|c|}
\hline Konfigurasi & Transmitter & Receiver \\
\hline MAC & $\begin{array}{c}\text { 0013A200419 } \\
\text { 76A9F }\end{array}$ & $\begin{array}{c}\text { 0013A200419 } \\
\text { 2F0BD }\end{array}$ \\
\hline CH Channel & C & C \\
\hline PAN ID & 1234 & 1234 \\
\hline Destination Address High & 0 & 0 \\
\hline Destination Address Low & 1 & 2 \\
\hline 16-bit Source Address & 2 & 1 \\
\hline
\end{tabular}

Sinyal atau informasi yang diperoleh tersebut diolah kembali oleh mikrokontroler pada bagian keluaran. Jika informasi yang diperoleh adalah sensor mendeteksi beban berlebih maka mikrokontroler akan mengaktifkan buzzer $12 \mathrm{~V}$ atau alarm peringatan, LED merah akan menyala dan motor servo akan bekerja sebagai penghalang pintu tertutup. Motor servo merupakan sebuah motor DC atau aktuator putar (motor) yang dapat diatur untuk menentukan dan memastikan posisi sudut dari poros output motor. Motor servo dapat menampilkan gerakan 0 derajat, 90 derajat hingga 360 derajat. Motor servo seperti pada Gambar 6 dapat bekerja searah maupun berlawanan arah jarum jam, sehingga motor servo yang dipasang pada engsel pintu kendaraan dapat menghalangi penutupan pintu ketika sensor beban mendeteksi beban berlebih pada kendaraan.

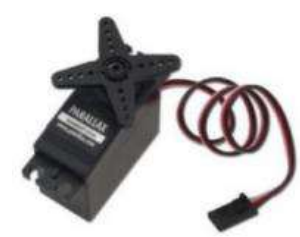

Gambar 6. Motor Servo

Informasi yang diterima oleh $x$ bee pada bagian keluaran, juga akan mengaktifkan relay. Relay merupakan komponen elektronika yang berfungsi sebagai saklar atau switch elektrik yang dioperasikan secara listrik. Prinsip kerja relay menggunakan prinsip elektromagnetik untuk menggerakkan saklar sehingga arus listrik yang kecil dapat menghantarkan listrik bertegangan tinggi.

Iron core (besi) yang dililitkan oleh kumparan coil berfungsi untuk mengendalikan iron core tersebut. Ketika kumparan coil dialiri arus listrik, maka akan timbul gaya elektromagnet yang akan menarik armature yang sebelumnya berposisi $\mathrm{NC}$ (normally close) ke posisi NO (normally open). Armature tersebut akan kembali ke posisi close saat tidak dialiri arus listrik. Perpindahan posisi armature hanya membutuhkan arus yang kecil. 4 channel relay seperti pada Gambar 7 merupakan relay dengan empat output. Output tersebut memiliki 3 pin terminal blok yang ditandai dengan NO, COM dan NC. Jika pada kondisi beban berlebih, relay yang sebelumnya bersifat $\mathrm{NO}$ akan bersifat NC sehingga akan menghentikan kinerja mesin.

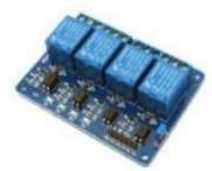

Gambar 7. Modul relay 4 Channel 
Desain dari keseluruhan sistem MASS dapat dilihat pada Gambar 8 .

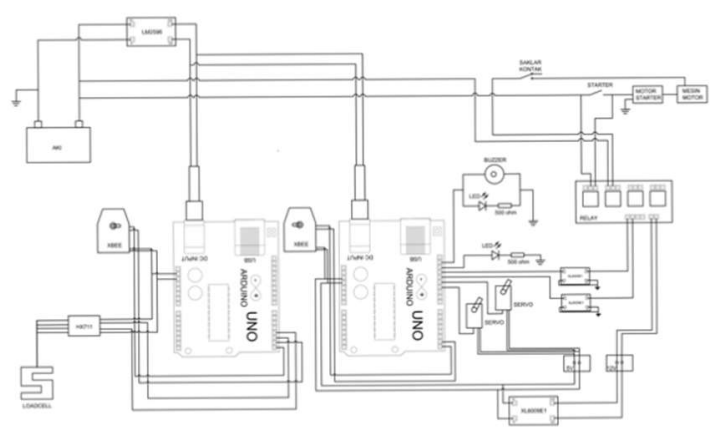

Gambar 8. Desain sistem MASS.

\subsection{Pembuatan Prototipe}

Prototipe yang dibuat adalah prototipe yang menyerupai truk dalam skala kecil. Dalam pembuatan prototipe terdapat dua komponen utama yaitu chassis (rangka) dan body (badan) kendaraan. Chassis yaitu rangka yang berfungsi sebagai kedudukan mesin, penopang berat dan pengemudi. Jenis rangka yang digunakan dalam pembuatan protipe ini adalah ladder frame. Rangka jenis ini dipilih agar meminimalisir penggunaan material tanpa menghilangkan aspek kekuatan dari rangka tersebut. Rangka prototipe dapat dilihat pada Gambar 9.

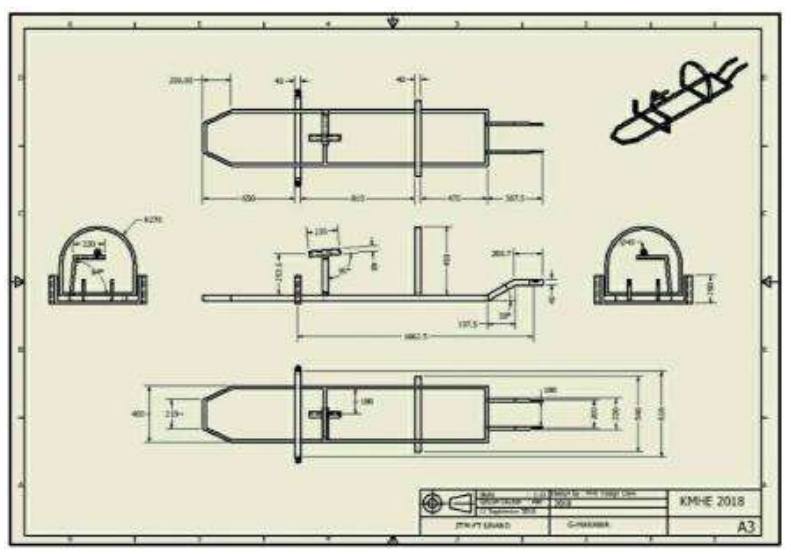

Gambar 9. Rangka Prototipe MASS

Perancangan prototipe MASS dapat dilihat pada Gambar 10.

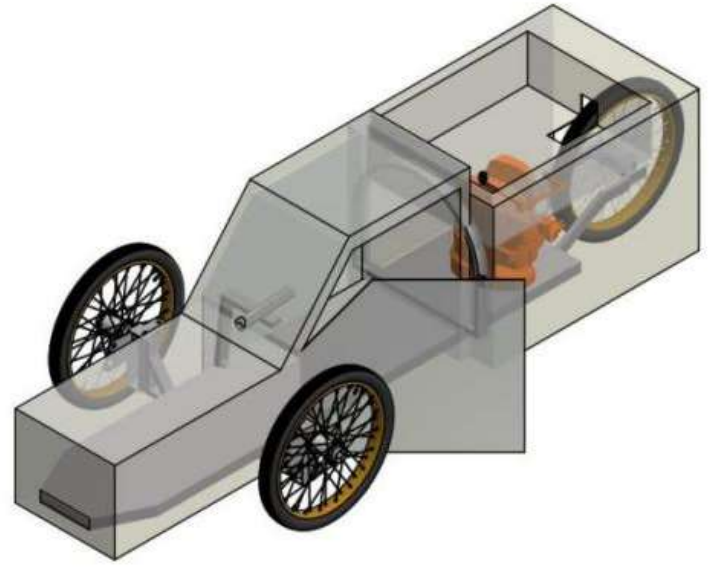

Gambar 10. Perancangan prototipe MASS

\section{Hasil dan Pembahasan}

\subsection{Peletakan Sensor Beban}

Sensor beban load cell diletakkan pada posisi yang mangalami momen terbesar. Artinya sensor akan diletakkan pada posisi yang mengalami pelendutan akibat pertambahan beban maksimal. Berikut adalah rancangan perhitungan mengenai chassis untuk peletakan sensor beban:

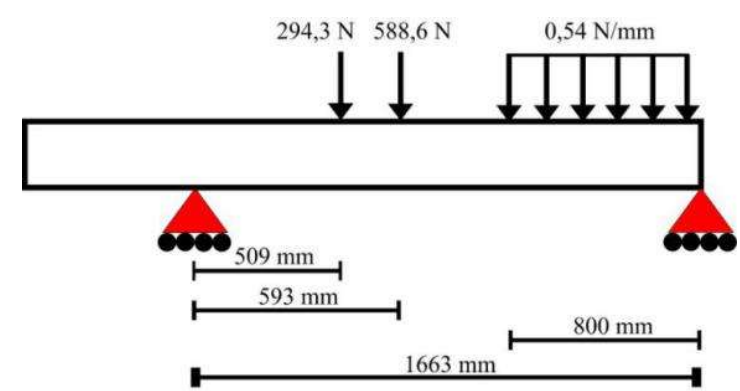

Gambar 11. Pembebanan pada rangka kendaraan

Berdasarkan Gambar 11 di atas, maka diperoleh diagram benda bebas seperti berikut:

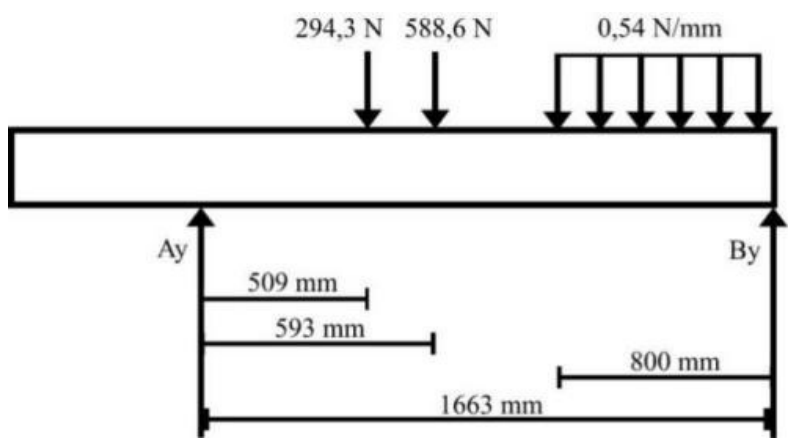

Gambar 12. Diagram benda bebas 
Jika $\sum F$ merupakan jumlah keseluruhan gaya eksternal pada rangka dan $\sum M$ merupakan jumlah keseluruhan momen yang terjadi pada rangka, maka

$$
\begin{aligned}
& \sum F_{y}=0 \\
& A_{y}+B_{y}=294,3 \mathrm{~N}+588,6 \mathrm{~N} \\
& +[(0,54 \mathrm{~N} / \mathrm{mm}) 800 \mathrm{~mm}] \\
& A_{y}+B_{y}=1314,9 \mathrm{~N} \\
& \text { dan } \\
& \sum M_{A}=0 \\
& B_{y}(1663 \mathrm{~mm})=(294,3 \mathrm{~N})(509 \mathrm{~mm}) \\
& +(588,6 \mathrm{~N})(593 \mathrm{~mm}) \\
& +(0,54 \mathrm{~N} / \mathrm{mm})(800 \mathrm{~mm})(1263 \mathrm{~mm}) \\
& B_{y}=628,05 \mathrm{~N}
\end{aligned}
$$

dengan mensubtitusi (3) dan (6) didapatkan $A_{y}+B_{y}=1314,9 \mathrm{~N}$

$A_{y}=1314,9 \mathrm{~N}-628,05 \mathrm{~N}$

$A_{y}=686,85 \mathrm{~N}$

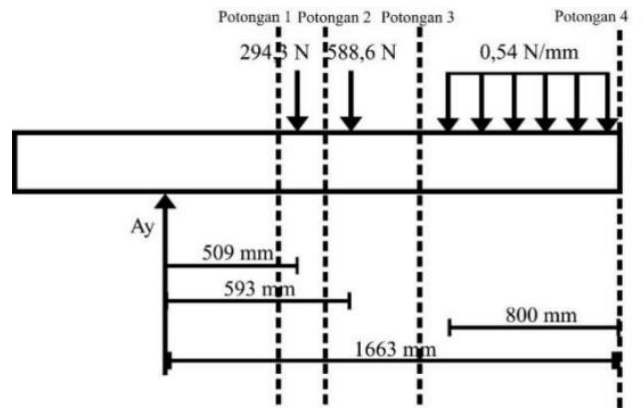

Gambar 13. Titik pemotongan pada rangka

Gambar 13 menunjukkan potongan diagram bebas dari rangka. Diagram bebas diptong menjadi 3 bagian untuk selanjutnya dianlisis masing-masing bagiannya. Pada potongan pertama, seperti yang ditunjukkan pada gambar 14a, diperoleh

$$
\begin{aligned}
& M=A_{y} \times x \\
& M=686,85 x
\end{aligned}
$$

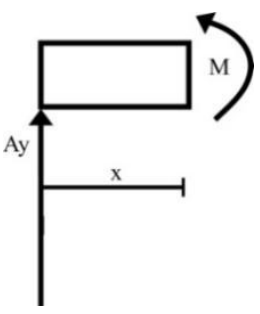

(a)

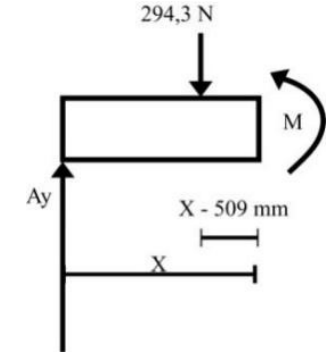

(b)

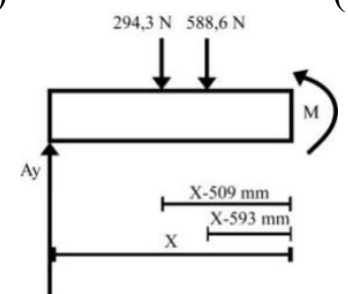

(c)

Gambar 14. (a) Pemotongan 1, (b) Pemotongan 2, dan (c) Pemotongan (3)

Sedangkan untuk potongan 2 yang ditunjukkan pada gambar $14 \mathrm{~b}$ diperoleh persamaan momen

$$
\begin{aligned}
& A_{y} x=M+(294,3)(x-509) \\
& 686,85 x=M+294,3 x-149798,7 \\
& M=392,55 x+149798,7
\end{aligned}
$$

Kemudian pada potongan 3 yang ditunjukkan pada Gambar 16 didapatkan persamaan momen

$$
\begin{gathered}
A_{y} x=M+(294,3 \mathrm{~N})(x-509) \\
+(588,6 \mathrm{~N})(x-593) \\
686,85 x=M+294,3 x-149798,7 \\
+588,6 x-349039,8 \\
M=-196,05 x+498838,5
\end{gathered}
$$

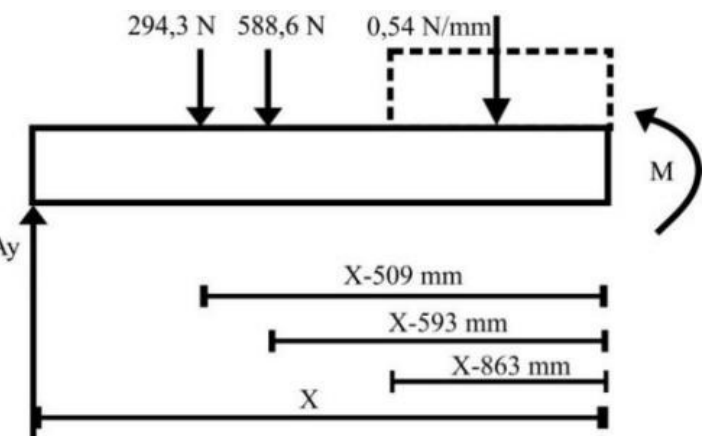

Gambar 15. Total gaya dan momen pada rangka

Sementara itu, berdasarkan gambar 15 diperoleh momen total pada rangka sebagai berikut 
$A_{y} x=M+294,3 N(x-509)$

$$
\begin{gathered}
+588,6 N(x-593)+\frac{0,54 N / m m}{(x-836)(x-1263)} \\
M=-0,54 x^{2}+951,99 x+89744,76
\end{gathered}
$$

Berdasarkan distribusi gaya pada (19), dapat diperoleh diagram momen yang ditujunkkan pada Gambar 16.

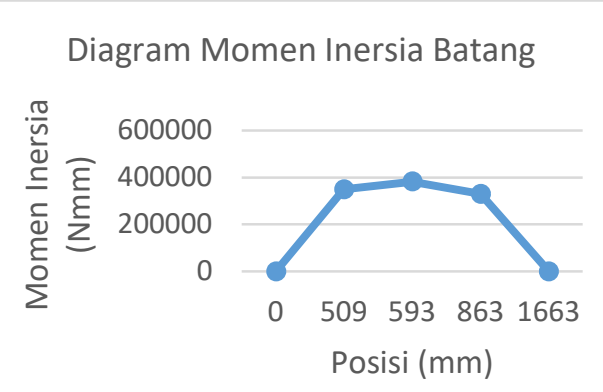

Gambar 16. Diagram momen inersia pada chassis.

Perhitungan momen dan berdasarkan grafik yang diperoleh nilai momen terbesar pada jarak 593 $\mathrm{mm}$ dari roda depan. Sehingga sensor beban load cell akan diletakkan pada posisi yang mengalami pelendutan maksimal, yaitu pada jarak $593 \mathrm{~mm}$ dari roda dari roda depan seperti pada Gambar 17.

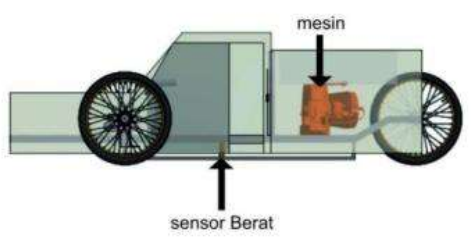

Gambar 17. Peletakan sensor load cell.

Pengujian sensor load cell dilakukan untuk menentukan tingkat keakurasian pembacaan sensor terhadap berat serta persentase keakurasian pembacaan sensor terhadap berat beban dan persentase nilai kesalahan error yang terjadi saat pembacaan beban. Untuk menghindari kesalahan (error) dilakukan kalibrasi saat sensor diletakkan pada chassis prototipe. Pengaturan beban yang diberikan pada arduino agar load cell mendeteksi overload 84 (64 kg berat penumpang dan $20 \mathrm{~kg}$ berat beban tambahan). Pengujian penambahan beban dapat dilihat pada Tabel 2 .

\begin{tabular}{|c|c|c|c|c|c|c|}
\hline \multirow{2}{*}{ No } & \multirow{2}{*}{$\begin{array}{c}\text { Beban } \\
\text { (kg) }\end{array}$} & \multicolumn{4}{|c|}{ Indikator } & \multirow{2}{*}{ Hasil } \\
\hline & & Alarm & LED* & Mesin & Pintu & \\
\hline 1 & 77 & Off & Hijau & Hidup & $\begin{array}{c}\text { Tidak } \\
\text { terhalang }\end{array}$ & Berhasil \\
\hline 2 & 79 & Off & Hijau & Hidup & $\begin{array}{c}\text { Tidak } \\
\text { terhalang }\end{array}$ & Berhasil \\
\hline 3 & 81,5 & Off & Hijau & Hidup & $\begin{array}{c}\text { Tidak } \\
\text { terhalang }\end{array}$ & Berhasil \\
\hline 4 & 84 & Off & Hijau & Hidup & $\begin{array}{c}\text { Tidak } \\
\text { terhalang }\end{array}$ & Berhasil \\
\hline 5 & 86 & On & Merah & Mati & Terhalang & Berhasil \\
\hline 6 & 90 & On & Merah & Mati & Terhalang & Berhasil \\
\hline 7 & 92 & On & Merah & Mati & Terhalang & Berhasil \\
\hline 8 & 76 & Off & Hijau & Hidup & $\begin{array}{c}\text { Tidak } \\
\text { terhalang }\end{array}$ & Berhasil \\
\hline 9 & 74 & Off & Hijau & Hidup & $\begin{array}{c}\text { Tidak } \\
\text { terhalang }\end{array}$ & Berhasil \\
\hline 10 & 71 & Off & Hijau & Hidup & $\begin{array}{c}\text { Tidak } \\
\text { terhalang }\end{array}$ & Berhasil \\
\hline
\end{tabular}

Tabel 2. Hasil pengujian pada sistem MASS.

* Led berwarna merah mengindikasikan kendaraan dalam kondisi overload dan berwarna hijau mengindikasikan kendaraan tidak overload.

Sensor beban load cell membaca beban yang terdeteksi pada chassis secara real-time setiap dua sekon. Durasi pembacaan beban tersebut di atur selama dua sekon agar pengiriman informasi ke mikrokontroler untuk mengolah data tidak terlalu cepat. Hasil pengujian dari Tabel 2 dapat dilihat bahwa pengoperasian prototipe menunjukkan bahwa sistem MASS yang diujikan mampu mengukur berat beban secara tepat sehingga mampu memberikan tindakan sesuai dengan program yang telah ditanamkan pada mikrokontroler. Keakurasian pengujian tersebut mencapai $100 \%$. Hal ini dapat dilihat bahwasanya pada 10 kali percobaan sistem telah dapat bekerja secara efektif memberikan perlakuan sesuai dengan kondisi beban yang diberikan.

Prototipe MASS "Mahine-Stopping System" merupakan prototipe yang bekerja dengan sensor beban load cell yang di tempat pada chassis kendaraan adalah prototipe yang menyerupai mobil angkut bak terbuka. Pengembangan alat ini meliputi otomatisi kerja load cell yang terintegrasi dengan relay, buzzer, led dan motor servo sebagai indikator yang menghalangi kendaraan beroperasi dalam keadaan muatan berlebih. Sumber energi listrik dari prototipe MASS untuk mengaktifkan sistem diperoleh dari aki $12 \mathrm{~V}$ kendaraan. 


\section{Kesimpulan}

Peletakkan sensor load cell adalah pada posisi $593 \mathrm{~mm}$ dari roda depan. Posisi ini diperoleh berdasarkan hasil perhitungan distribusi gaya pada chassis kendaraan yang mengalami pelendutan maksimal. Performansi yang dihasilkan oleh sensor load cell yang dibuktikan dengan 10 kali pengujian adalah sensor mampu mendeteksi beban dengan rata-rata waktu pembacaan dua sekon. Hal ini menunjukkan bahwa sensor sangat resistif terhadap perubahan beban sehingga mampu mendeteksi perubahan beban dengan cepat. Pembacaan sensor load cell dengan tepat akan membunyikan alarm peringatan, mematikan mesin kendaraan dan menghalangi penutupan pintu. Pada pengujian tersebut sensor mampu mendeteksi berat beban dengan baik. Pengujian tersebut membuktikan tingkat keefektifan sistem bekerja mendeteksi beban dan bekerja adalah $100 \%$.

\section{Ucapan Terima Kasih (Acknowledgement)}

Penulis mengucapkan terima kasih kepada Kementerian Riset dan Perguruan Tinggi yang telah memberikan dana agar kegiatan PKM-KC ini dapat terlaksana dengan baik berdasarkan Surat Keputusan No. B/ 81/B.B3/KM/02.01/2019 Maret 2019.

\section{Daftar Pustaka}

[1] T. R. Zulkarnaen, "IMPLEMENTASI KEBIJAKAN PENGAWASAN DAN PENGENDALIAN MUATAN LEBIH (Studi Kasus pada Unit Pelaksana Penimbangan Kendaraan Bermotor Dinas Perhubungan Provinsi Sumatera Utara)," vol. 2, no. 1, hal. 209-231, 2011.

[2] E. Afrizal, N. Carlo, dan Rahmat, "Analisa pengaruh muatan berlebih terhadap umur rencana perkerasan jalan," Universitas Bung Hatta, 2014.

[3] W. Wahyudi, A. T. Mulyono, dan W. Santosa, "Pengaruh muatan lebih beban gandar kendaraan berat angkutan barang terhadap peningkatan oksida karbon," Transportasi, vol. 13, no. 2, hal. 85-92, 2013.

[4] Y. Deng dan B. M. Phares, "Automated bridge load rating determination utilizing strain response due to ambient traffic trucks," Eng. Struct., vol. 117, no. June, hal. 101-117, 2016.
[5] D. B. Susilo, H. Wibawanto, dan A. Mulwinda, "Prototype Mesin Pengantar Barang Otomatis Menggunakan Load Cell Berbasis Robot Line Follower," Sci. J. Informatics UNNES, vol. 10, no. 1, hal. 2329, 2018.

[6] A. Yudamson, A. Trisanto, dan F. X. A. Setyawan, "Rancang Bangun Model Lift Cerdas 3 Lantai Dengan Menggunakan PLC Omron Zen 20C1AR-A-V2," hal. 1-9.

[7] L. Limasari, "RANCANG BANGUN PENGUKUR MASSA MENGGUNAKAN LOADCELL BERBASIS MIKROKONTROLER AT89S51," universitas DIPONEGORO, 2009.

[8] Avia, "HX711 datasheet $\{24-B$ it Analog-toDigital Converter (ADC) for Weigh Scales\}," vol. 9530, no. 592, hal. 1-9, 2019. [9] M. Mcroberts, Beginning Arduino. Paul Manning, 2010.

\section{Biodata Penulis}

Rifki Firdaus, Saat ini sedang menempuh pendidikan sarjana di Jurusan Teknik Elektro Fakultas Teknik Universitas Andalas dengan Program Studi Teknik Kendali.

Lucyana Lufti, Saat ini sedang menempuh pendidikan sarjana di Jurusan Teknik Elektro Fakultas Teknik Universitas Andalas dengan Program Studi Teknik Kendali.

Muhammad Habib Anshor, Saat ini sedang menempuh pendidikan sarjana di Jurusan Teknik Mesin Fakultas Teknik Universitas Andalas dengan Program Studi Konversi Energi.

Rahmadi Kurnia, Menyelesaikan pendidikan sarjana dari Universitas Indonesia Jurusan Elektro pada tahun 1995. Pada tahun 1998 menyelesaikan pendidikan magister dari Universitas Indonesia Jurusan Teknik Elektro Pendidikan doktor diselesaikan pada tahun 2006 dari Saitama University, Jepang. Saat ini mengajar pada Jurusan Teknik Elektro Universitas Andalas, Padang. 